\title{
Recent Methodologies for the Synthesis and Applications of Oxazine Compounds
}

\author{
Mohammad S Al-Ajely* \\ Department of Chemistry, Education College for Girls, Mosul University, Mosul, Iraq \\ *Corresponding author: Mohammad S Al-Ajely, Department of Chemistry, Education College for Girls, Mosul University, \\ Mosul, Iraq
}

\section{ARTICLE INFO}

Received: 幽 January 07, 2021

Published: 蔧 January 15, 2021

Citation: Mohammad S Al-Ajely. Recent Methodologies for the Synthesis and Applications of Oxazine Compounds. Biomed J Sci \& Tech Res 33(2)-2021. BJSTR. MS.ID.005363.

\section{ABSTRACT}

In this short review we will concentrate on the newest methods for the synthesis of this type of important heterocyclic compounds. This type of compounds have proved to have valuable pharmaceutical and medical applications as drugs and co drugs for numerous types of diseases starting from microorganism screening to cancer cells treatments and have been succeeded in all types of these therapeutic and medical fields.

Keywords: Methodology; Synthesis; Oxazine; Recent

\section{Introduction}

Oxazine compounds have been investigated by Chaitra G. and Rohini RM., They prepared these compounds from chalcone derivatives of pyridine and studied there screening effects towards inflammatory and as antioxidants [1]. Vashundhra Sharma and his coworkers have also studied the synthesis of these compounds and have proved that these compounds are very effective toward cancer cells killing [2]. During 1919 some researchers have tested the synthesized compounds 3,4-dihydro-2H-1,4-benzoxazin-3-one derivatives toward human DNA topoisomerase I, the study showed effective inhibitory activity which might serve as novel constructs for future anticancer agent deigns [3]. Nabawey and his team have reviewed the synthesis of 3,4-Dihydro-2H-1,3benzoxazines by Mannich reaction and studied their biological actions [4]. Seyed Gholamhossein and his coworkers have investigated the synthesis of naphtha [1,2-e] [1,3] oxazines bearing an alsulfonamide moiety their investigation have revealed the remarkable activity against cancer cells and as anti-inflammatory agents [5].

\section{Results and Discussion}

According to the above brief summary for the methods for preparation of this type of compounds which were proved their successful action towards wide spectrum of medical actions encourage many researches to find new methodologies for their synthesis and also encouraged us to use new methods for the synthesis of different types of new oxazine compounds [610]. We also studied some of their biological effects towards microorganisms, our investigation revealed the promising results for most of the prepared compounds in which these compounds might find its way to be used as drugs [11]. That is our nest study during our present program.

\section{References}

1. Chaitra G, Rohini RM (2018) Synthesis of 1,3-0xazine derivative from Chalcone and Screening for their Anti-Oxidant and Anti-Infl ammatory activity. International Research Journal of Pharmaceutical and Biosciences 4:19-27.

2. Sharma V, Jaiswal PK, Saran M, Yadav DK, Saloni, et al. (2018) Discovery of C-3 Tethered 2-oxo-benzo [1,4] oxazines as Potent Antioxidants: BioInspired Based Design, Synthesis, Biological Evaluation, Cytotoxic, and in Silico Molecular Docking Studies. Front Chem 6: 56.

3. Foto E, Özen C, Zilifd F, Betül, Gülbașilkay T (2020) Benzoxazines as new human topoisomerase I nhibitors and potential poisons. DARU Journal of Pharmaceutical Sciences 28: 65-73.

4. Nabaweya S (2020) 3,4-Dihydro-2H-1,3-benzoxazines and their oxoderivatives chemistry and bioactivities. J Serb Chem Soc 85(5): 1-36.

5. Mansouria S, Boei $\mathrm{H}$, Zomorodian $\mathrm{K}$, Khalvati B, Pargali RH, et al. (2020) Synthesis of novel naphtho[1,2-e] [1,3] oxazines bearingan arylsulfonamide moiety and their anticancer and antifungal activityevaluations. Arabian Journal of Chemistry 13(1): 1271-1282. 
6. Al-Ajely, Noori AM (2019) Synthesis of New Oxazin Compounds Derived from Furfural, Chalcons and Schiff Bases. J of Pharmacology and clinical research 1(3): 66-71.

7. Al-Ajely, Norri A (2020) An Efficient and Solvent Free Synthesis of N-Aryl 2,3-Dihydro-4H naphtho-[2,1-e] 1,3-oxazines. Bio medical journal of scientifi cand technical research 29(3): 22510-22516.

8. Ghufran S, Al-Ajely, Neim H (2020) New Approach for the Synthesis of Aryloxy 1,3-Oxazines. Journal of Material Sciences \& Manufacturing Research 1(2): 1-5.

ISSN: 2574-1241

DOI: $10.26717 /$ BJSTR.2021.33.005363

Andrey Molyakov. Biomed J Sci \& Tech Res

(C) (P) This work is licensed under Creative

Submission Link: https://biomedres.us/submit-manuscript.php
9. Sadeek T, Ghufran, Al-Ajely, Neam H (2020) Synthesis of Some Oxazine Compounds Derived from TDI and Schiff Bases. Acta Scientific medical sciences 4(9): 20-28.

10. Sadeek T Ghufran. Al-Ajely, Neam H (2020) Synthesis of some oxazine compounds derived from phenols \& 8-hydroxy quinolone. Solid State Technology 63(5): 3179-3190.

11. Gufhran T Sadeek (2021) Synthesis of some oxazine compounds and the study of their biological activities PhD. Thesis Mosul University, Iraq.

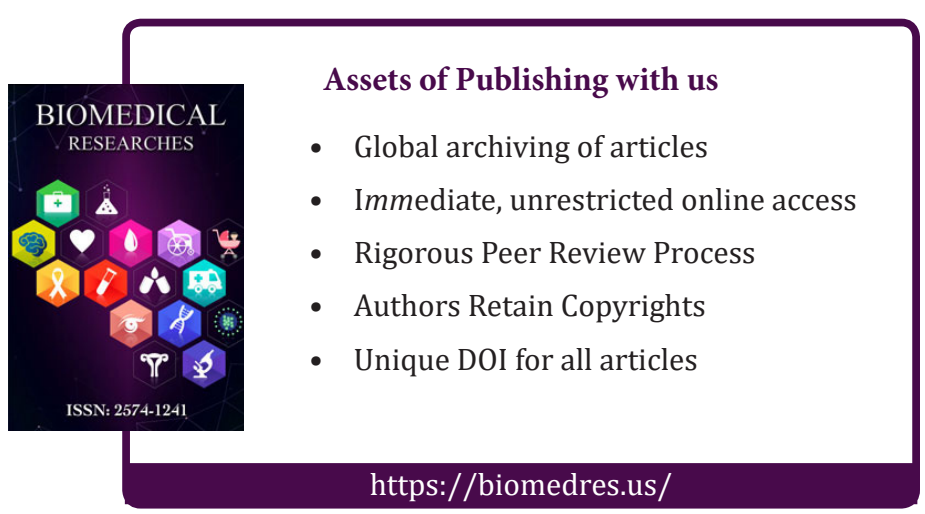

